\title{
13 Policing sorcery accusation related violence in Papua New Guinea
}

\author{
Miranda Forsyth
}

\section{Introduction}

This chapter describes how the police in Papua New Guinea (PNG) respond to sorcery accusations and related violence (SARV). In so doing, it opens a portal through which the relationship between the police, the state and the public can be viewed and analysed. SARV offers a unique angle from which to view these relationships because it often involves a clear conflict between differing conceptions of what actions are in the public interest and what constitutes a source of insecurity. At its most extreme, SARV pits an entire community convinced of the need to torture and kill the sorcerer (or witch), whom they believe has killed and may kill again, against a state whose laws proscribe the death penalty for those who take such actions. The police, as one interviewee neatly put it, are the "meat in the sandwich".

This chapter first investigates the successive challenges the police in PNG face when seeking to police SARV. Like much of the literature in this area, it highlights the vast array of difficulties faced by the police - including their lack of sufficient personnel, training, resourcing and oversight. It also describes the particular problems SARV presents on top of this familiar litany of problems - the moral dilemmas faced by police officers when they themselves are convinced of the reality of the sorcery claims, and the risks to their own lives from the mob violence that often accompanies SARV incidents. In such a context, there are competing conceptions of security at play - the security of the community in terms of needing to be protected from potential supernatural harm, and the security of individuals needing to be protected from stigmatisation and attacks following accusations of sorcery. Not only does this pit individual security against public security, it also pits a magical world-view against a secular/scientific one.

The chapter then steps away from a "deficit lens" approach to policing and turns to describing a number of strategies used by those police who do respond effectively to SARV. Many of these strategies revolve around the non-policing relationships and resources that the police officers possess as members of clans and tribes, as members and leaders of different Christian congregations, as supporters of particular political factions and as participants and leaders in a wide range of community leadership roles. 
The importance of non-state policing resources is a familiar theme in the literature of policing in the global South (and in the global North, within the frame of community policing and private security). However, the chapter does not identify the importance of this web of relationships in order to make the now familiar argument about the need to recognise and appreciate the broad range of non-state policing resources. Whilst it agrees with this standpoint, it goes further to ask what the empirical evidence about the policing of SARV tells us about the relationship between the police and the state, a relationship that has not been interrogated often, not even in the literature focussed on plural policing.

The chapter makes the argument that there are at least two models of relationship between state, police and community in PNG. One is the classic Weberian state, existing in some bureaucratic structures, institutional arrangements and most importantly, as an ideology. In this model the police, who have a legitimate monopoly on the use of force, carry out the wishes of the state on the community. The other model is a far older relational state, where the drivers of action are the relational properties that exist between individuals and institutions. In this model, the police and community are connected in multiple different ways and act on each other. The relational model views the police force and other institutions of government as just one of multiple sets of relationships within which individuals are situated. Both of these models of state exist in different configurations of dynamic interaction and domination throughout PNG and are implicated in policing practices, such as in policing SARV.

The chapter finally sets out some of the theoretical and policy implications arising from this insight. It suggests the ability of police to effectively provide security for the weak and the vulnerable in PNG society may be enhanced by embracing their relational resources, and providing them with the moral and ethical skills needed to navigate effectively between conflicting cultural and state norms around the acceptability of violence.

\section{The various threats SARV poses to security in PNG}

Throughout Melanesia, sorcery and witchcraft provide an explanatory framework that makes sense of events in the world, especially illness, death and misfortune. In 2009, the PNG Constitutional Law Reform Commission reported on its extensive consultation and research into sorcery beliefs in PNG. It found the majority of Papua New Guineans strongly assert that sorcery is real, regardless of levels of education, gender, religiosity, or whether they reside in urban (including overseas) or rural areas. One effect of believing in witchcraft is an assumption that others desire to do them harm. Ashforth $(2005$, p. 69) uses the notion of "spiritual insecurity" to explain the impact produced by belief in witchcraft, noting: "life in a world of witches must be lived in the light of a presumption of malice: one must assume that anyone with the motive to harm has access to the means and that people will cause harm because they can".

In PNG today, belief in sorcery frequently leads to accusations against individuals suspected of practising sorcery, particularly in the context of unexplained 
or unexpected sickness and death. Such accusations can lead to stigmatisation (and social isolation), violence and even death. Activists within PNG have coined the term "Sorcery Accusation Related Violence" (SARV) to refer to this bundle of harms, signifying that it is violence emanating from the accusation, rather than the supposed power of sorcery that underlies the harms. Increasingly, it is globally recognised that SARV (sometimes referred to as "witch-hunting") is a form of extreme human rights violation and that it is occurring in many countries (Forsyth, 2016; WHRIN, 2017).

The scope of the harms related to SARV have not yet been properly quantified. However, halfway through a multi-year research project documenting as many cases as possible in three provinces, the chapter's research team has recorded 357 incidents of sorcery accusations since $2016 .{ }^{1}$ The data about each of these incidents is recorded on a standardised form by a network of local field recorders in each province, referred to below as "incident data". ${ }^{2}$ So far the data shows 117 of these 357 incidents led to violence against 185 victims and 240 did not lead to violence. In almost a quarter of the SARV incidents, the victim's family had to temporarily relocate and $16 \%$ did so permanently. Our analysis of cases reported in the national media and by the national courts over a 20 -year period found that in the reported cases, almost half the accused were killed (42\%), a third were wounded (34\%) and a third (34\%) were not physically harmed. (On average, there were more than 30 deaths and 72 victims per year (Forsyth, Putt, Bouhours, \& Bouhours, 2017b).

The formal state legislative response to SARV in the past decade has involved the repeal of the Sorcery Act $1971^{3}$ and the introduction of a new provision into the Criminal Code that creates a specific offence of "wilful murder of a person on account of accusation of sorcery" (s299A). Whilst each year there are between seven to eight convictions for murder involving accusations of sorcery, ${ }^{4}$ the vast majority of cases of murder, grievous bodily harm, assault, arson and destruction of property associated with accusations of sorcery do not proceed very far, if at all, through the criminal justice system. This fact has been repeatedly commented upon by local activists and external commentators, including various United Nations (UN) human rights representatives. ${ }^{5}$

\section{The challenges of policing SARV}

As in many parts of the global South, security in PNG is provided by a broad network of actors and institutions, often acting together in assemblages (Lattas \& Rio, 2011) or in nodal relationships (Shearing, 2005). SARV is therefore policed by a variety of different actors, particularly local leaders and faith-based organisations, but this chapter focusses principally on the police response.

The official police force in PNG is the Royal Papua New Guinea Constabulary (RPNGC), estimated in 2013 at around 5,724 uniformed police (Connery \& Claxton, 2014), which is less than half the UNs' recommended minimum. ${ }^{6}$ Given the uneven geographical distribution of police, with most clustered in urban areas, there are many areas of PNG effectively left unpoliced by the RPNGC. Training of uniformed police takes just six months. Uniformed police are supplemented by 
community auxiliary police (CAPs) and reserve police officers, both drawn from the wider community. ${ }^{7}$ CAPs receive 2-6 weeks training and notionally get paid a small salary, which frequently fails to materialise.

The various challenges facing the RPNGC and the CAPs/ reserves have been detailed over the years without great variation, except perhaps with an increasingly negative and desperate tone (see Dinnen \& McLeod, 2009). Peake and Dinnen $(2014$, p. 34) note that "[i]t is striking that the language used to diagnose the RPNGC's frailties in 2014 is practically identical to that used at the beginning of the first programme [25 years ago]". These challenges include the manifestly inadequate size of the force; lack of essential resources, such as vehicles and fuel; lack of regular training, such as investigatory techniques; substandard police leadership; factionalism; political interference in police operations; lack of responsiveness to community complaints and high levels of police brutality (Putt, Dinnen, Keen, \& Batley, 2017). Extracurricular means of raising funds, through political patronage and "fuel" money from individuals seeking help or reporting a crime have also been reported (Dinnen, 2017). The last major review, in 2004 ("the 2004 review"), found "weaknesses in every area and aspect of the constabulary". ${ }^{8}$ That review also noted that the most widespread philosophy amongst the Constabulary still carried a colonialist notion of "enforcing the rules on a suspicious population", despite prior recommendations in various reports to evolve to a community policing philosophy. ${ }^{9}$

These generalised capacity challenges impact the RPNGC's ability to prevent and intervene in incidents, and to bring perpetrators of SARV to justice. For instance, in one Highlands province, a CID officer explained they had no assigned vehicle since 2015 and could only access a station vehicle occasionally. Specialist squads, such as the homicide squad, no longer existed, and he described his policing approach as "investigating cases as they come in", rather than having capacity to go out to remote places to conduct interviews and investigate. He mentioned a case where a woman was accused and tortured, including by her brother, who is "still at large and won't surrender". In another case, a young girl was accused and tortured. Although the police have evidence to identify the suspects, the remoteness of the location, across two rivers with no bridge, makes it hard to arrest them. The police officer in charge explained how he went three times to try to arrest the suspects, but people refused to talk about it. He said that if he used force, then they would probably remove some of the bridges to trap him and try to shoot him. Instead, he had to resort to other more dialogue-based and relational tactics.

The policing response to SARV is further complicated by various factors that are more particular to the issue. These stem largely from the disjuncture between the official state response to SARV as a crime and broad community support for violence against those believed to have used sorcery, particularly where the accused sorcerer is considered to have killed someone through their sorcery and remains a threat. The impacts of this disjuncture are:

- $\quad$ Police are frequently not notified about SARV incidents. Based on our incident data collected in three locations, the police were called in just over a quarter of the incidents that resulted in violence. 
- Police are hampered in intervening to protect those being attacked by the community (outnumbered and outgunned). In $23 \%$ of cases we have collected to date across the three provinces, over 50 perpetrators are involved, frequently blocking police access and threatening violence against police attempts to intervene.

- Police cannot persuade witnesses to testify in court. For instance, in one Highlands province, a CID officer said: "We need statements, most witnesses won't do it. Whole tribe against an individual. Nobody supports the victim. . . . The community decides what they want to say to the police".

Some police are complicit in SARV and act as passive bystanders or even perpetrators, sharing the same views as the community about the suspected sorcerer. In one recent case, the Northern Provincial police commander was even the instigator of SARV; he became convinced that his sore leg was caused by two individuals in his home village using sorcery against him, and sent two of his officers to assault them, leading to the death of one of the accused and serious bodily harm the other. ${ }^{10}$

As a result of all these (and other) challenges, the proportion of incidents that result in arrests is low, at $9 \%$ according to our incident data and at $20 \%$ according to the 20 years of reported cases in national newspapers and courts we have analysed. The percentage of incidents resulting in convictions is even lower.

A related issue for the police trying to police SARV is how they should respond if approached by community members concerned that a particular individual or individuals are practising sorcery. The strict legal position is that sorcery is not a crime under the criminal law, although the Village Courts have a number of sorcery-related offences that criminalise the pretence of sorcery. We have documented a wide range of responses to such concerns, including: police detaining the accused and launching full investigations; ${ }^{11}$ explaining that "there is no evidence" to prove sorcery under the law and sending people back to their villages or communities to deal with the matter there; mediation (discussed in the next section); advising community members to seek compensation from the suspected sorcerer; imprisoning the suspect, sometimes with and sometimes against his or her will ${ }^{12}$ and as mentioned earlier, becoming active participants in violence against those accused.

\section{Police strategies to address SARV}

There are multiple instances where police intervention does occur through prevention, intervention and prosecution, as well as provision of safety to those accused, despite significant obstacles lying in the way of police assisting the victims of SARV. Four main policing strategies in relation to the SARV cases emerge from the examples of cases we have documented.

The first strategy involves forming coalitions with local powerbrokers and local community members, in order to both engage in prevention and to intervene to stop violence or to remove those being accused. One senior police officer in 
the Highlands reflected that while he had believed "in arrest and the rule of law" when he first worked in the province more than 15 years ago, he has subsequently taken a more "flexible view". Despite being well connected politically and high in the police hierarchy, he has to rely on provincial or more local patronage to obtain resources, such as fuel for the police vehicles, in order to even get to sites where intervention is required. Once at a rescue site, negotiation and strategic collaboration with local leaders is essential, given the imbalance of manpower between police and community. In Bougainville, we documented a number of cases where unarmed police teamed up with armed ex-combatants and community government leaders in order to rescue accused sorcerers who were being detained and beaten by community members.

Second, police informally mediate cases at the police station or in villages, seeking to enable communities to deal with their anxieties around sorcery in ways that do not involve violence. This type of mediation often involves encouraging people to voice their concerns and provide evidence to support their accusations, and in turn, giving the accused an opportunity to publicly respond with explanations about the alleged suspicious behaviour. For instance, a person seen in an odd place at an odd time may be suspected of sorcery, but they may have a simple explanation for their presence at that time that dispels suspicion. Through such mediation, the police perform the role of bridging the strict demands of the state's legal position (sorcery is irrational nonsense) and the genuine concerns of communities. Sometimes the police conduct the questioning themselves, other times they provide security for the meeting, and exercise their convening power to bring together community leaders, pastors or Village Court magistrates to do the actual mediating.

Third, the police frequently offer the accused refuge inside the police station and in its cells. Whilst on occasion there is a lack of clarity around whether or not the intention is to offer safety, or in fact to lock away a dangerous public menace, we have documented a substantial number of cases (in Bougainville, Lae, Port Moresby and in the Highlands) where the motivation is clearly to protect the accused individual. One example occurred in Port Moresby in late 2018, when a female police officer offered refuge to a woman accused by her in-laws of using sorcery to make her husband sick. Despite the disapproval of her superior officers, she kept the accused woman in the police station for a week, paying for her food and her baby's supplies, and even slept in the station with her. She helped the accused woman to find family members willing to take her in and support her. When asked what had motivated her to do this, the police officer replied: "I had no choice. I could see she needed help". She observed she was not concerned the woman was a sorcerer, because she had carefully assessed the evidence and concluded that the woman truly loved her husband and so trying to make him sick made no sense. She reflected that she was trying to make a difference through assisting one person at a time, and hoped that her gesture would spread. She believed that maybe if one day the woman she had helped saw someone else in a similar situation, she would advise them "go and see [name] the police officer, she will help you". 
Fourth, there are multiple cases where police have offered personal support and their own resources to care for victims of SARV and their families, taking them into their own houses at times, and exposing themselves to considerable risk to their own lives. In one case of SARV, one family's son was murdered, the fingers were chopped off another son and the father had had his whole hand chopped off. The police officer involved in the case stated: "my family agreed to assist these two on humanitarian grounds and so we allocated them some ground and some coffee plantation. They have been with us for four years now, we have not asked them for anything in return". When asked whether he was afraid of his own life for sheltering these men, he stated: "I am a paramount leader of my tribe. If anyone says anything bad against me they will be attacked by my tribesmen". This is an example of a police officer calling upon his tribal networks to allow him to exercise care and protection for victims, duties that are related to, but go well beyond, his role as a police officer.

Other police officers have set up initiatives within their own communities to avoid the type of extreme violence they have observed occurring in relation to SARV cases. For instance, one police officer in the Highlands described the way in which he had set up an association in his community to address social disorder: in cases of sorcery accusation, the association calls together members of different Christian denominations from within the community to weigh up the evidence, and find there is no real evidence. He further personally explains to the accusers that there could be other reasons behind the incident they have accused the "sorcerer" of causing, such as a biological explanation for sickness or death. This police officer observed that people listened to him because he has standing in the community and he has their respect, in part due to his role as police officer.

\section{Insights for the relationship between the police and the state}

It is helpful to situate this discussion in the context of a rich vein of scholarship on policing that has emerged over the past decade, ${ }^{13}$ which has, in different ways, critiqued the dominant model of policing, termed here the "police legitimacy model", (borrowed from Mendez-Beck \& Jaffe, 2019). This model involves "a relation where the police enforce a social and legal order posited by the state" (Mendez-Beck \& Jaffe, 2019, p. 4). It is based on a Weberian understanding of the state, whereby the police have a monopoly on the use of force, and the goal of policing is as much about providing the state legitimacy as it is about providing security and justice for people (Bayley \& Perito, 2010, p. 82). In this model, to use the helpful language of Braithwaite (2000), the state does "all the rowing and all the steering". Braithwaite (2000) argued that this model of the state reached its zenith in practice under a Keynesian ideology, later increasingly undermined by the turn to the market as regulator. In the context of policing, it means the police, as agents of the state, have the role of enforcing the law on the community.

Two interlinked policy-relevant consequences of these insights into the problems with the police legitimacy model of policing arise. One is the need for more 
active embrace by governments of "multi-choice policing" or "plural policing" to use policing resources outside of, or more loosely connected with, the state. The second is the turn to "community policing" as a way of recognising the need to involve communities more actively in both the steering and rowing of policing. The original, expansive vision of community policing was based on the logic that the police need to engage in lateral partnerships and collaborative efforts with other government organisations, structures of civil society and the private sector (Marks, Shearing, \& Wood, 2009, p. 146). Both of these approaches have been strongly advocated also in the context of PNG (for example, Peake \& Dinnen, 2014).

However, there has been strong resistance from governments in both the global North and the global South to any real engagement with both multi-choice policing and community policing as originally proposed (Marks et al., 2009). Both proposals have foundered at the point of the state being prepared to relinquish the ideological monopoly over policing within its particular territory. In regard to community policing, the notion has been "writ small" to become "[s]omething to make state police more effective by getting the community to help them" (Braithwaite, 2000, p. 230). In other words, the state enrols the community to do part of the rowing, but does not relinquish much real control over the steering, keeping intact its objectives to strengthen the legitimacy and effectiveness of the police (and hence the state).

The plural policing scholarship argues that it is important to recognise the existence of a diversity of policing actors in any given social field. A further, hitherto largely unexplored consequence of the insights emanating from this scholarship is that it is also necessary to rethink the model of the relationship between the police and the state. This, in turn, has implications for how the police interact with, influence and are influenced by, the other policing actors in the broader assemblages and networks within which they work.

In much of the literature discussed above, even that used to argue for community policing and plural policing, the police are seen as closed nodes tied very strongly to the state, reflecting the model strongly associated with the Weberian state. The emphasis is on control of police through rigid hierarchy and bureaucratic rationality. While the nodal governance literature encourages police to enrol others in their policing project, it still envisages them as a bounded entity - "the police" - and as total agents of the state (for example, [Shearing 2005]). Marks et al. (2009) envisage each node in the security governance, including the police, as "strong and distinguishable from the other" (p. 152). Any move of individual police officers outside this relationship of control is seen in purely negative terms, usually as corruption or co-option by non-police actors (be they criminal gangs, businesses, political parties or in a Melanesian context, wantoks [literally "one talk", meaning people from the same language group or family/clan/tribe]).

Yet, this model of relationship between the police and the state is very much at odds with the empirical reality, particularly in a country like PNG, but to some degree in many other countries as well. The reality is much more often the case that the police and other agents of the state exist within multiple relational 
networks wherein they exercise their powers to both steer and row governance at different scales.

Following these insights, this chapter suggests that the Weberian state is not the only form of state in existence in PNG (or indeed in many other countries). There is also a second form of state, the relational state. In this model, both the rowing and the steering rely upon the relational properties that exist between individuals and institutions as they are variously grouped and networked. The relational state acknowledges that relationships are the glue that holds the state together at a variety of different scales and the engine that drives much of the action - in many contexts they are the only things allowing it to operate at all. In the relational state, the police and community are connected in multiple different ways and act on each other and it is through these interactions that policing and the provision of security (as well as governance) largely occurs.

The relational state exists in dynamic interaction with the Weberian state in PNG, with each modifying and, in particular contexts, dominating each other. It is not correct, however, to conceptualise an evolutionary trend in which the Weberian state model slowly but surely dominates the relational state model (see, for example, the World Development Bank Report (2017) where this assumption is stark). Both the relational state and the Weberian state are better conceived as fully formed and fully modern, operating together to produce the governance arrangements of today. The consequence of this reframing means that it is a mistake to consider the relational state only in terms of the extent to which it can improve the Weberian state's scope, power and legitimacy. Instead, it should be asked how both might improve (and threaten) security and access to justice.

Evidence for the existence of the relational state largely comes from observations about how the police actually provide security to the victims of SARV. The strategies most frequently successful in this context can best be understood as belonging to the relational state, namely forming coalitions with other powerbrokers, use of informal strategies such as mediation, using state resources (such as police posts and prison cells) in ways unintended officially and personal donations of support and security. The relational state framing allows us to view what is happening not as the police failing to fulfil their functions (as in the classic diagnosis of "weak" or "failed" states), but as fulfilment of their functions through the modalities of the relational state, rather than the Weberian state.

The example of SARV shows that in order for the opportunities for less dominating visions of justice to emerge and be enforced, they must come from the interaction of both models with each other. A purely Weberian state approach achieves almost nothing in relation to SARV, because the state lacks the necessary manpower to apply an interpretation of security vastly at odds with community perceptions of security. A purely relational approach risks allowing mob violence to prevail, favouring tribal connections that are the strongest. However, the interactions between the two state models can provide the necessary range of resources, normative contestations and moral balancing that enable police officers to conceive and implement the various successful strategies outlined above. Whilst more research is needed to delve deeper into the various motivations of the police officers engaged in these approaches, the chapter has found a range of 
motivations. These include: perceptions of their obligations as police officers to provide security for those who seek their support; religious convictions; desire to maintain peace in their own communities and their compassion for the victims, which arises from a shared sense of humanity.

Following Braithwaite's injunction to seek to integrate the explanatory with the normative (2000, p. 235), it is necessary to consider the policy implications of the discussion above. One new policy orientation emerging from the nodal policing literature (Marks et al., 2009) is "minimalist policing". This approach advocates seeking to clearly delimit the police role to catching and charging perpetrators of crime, removing them from the more preventative work. However, this approach is unlikely to work in a country like PNG, as the approach is premised on a state that is strong and well-resourced enough to be able to effectively enforce a core role for the police. This chapter advocates a different approach: an embrace of the relational resources that police can and do draw upon to perform their role of provision of security writ large. Focussing only on the negatives associated with these relational resources (wantokism, corruption, etc.) ignores the reality that it is the relational leverage of police officers that allows them to perform any real role of security provision in PNG today. This means that conceptualising police as outsiders and neutral enforcers of the law may cut them off from the very resources they rely upon to do their job.

\section{Conclusion}

In conclusion, there is a need to understand that police officers and other state officials always operate both within webs of relationships and within the institutional structures and ideology of the Weberian state. Thus, there is a need to equip them to make the best use of this dual reality in carrying out their policing and other governance roles. Challenging the normative legitimacy of violence is now a priority, as well as actively seeking to discover where the interactions of the two models of state best generate policing that achieves the visions of justice sought by community members, protection of the weak and promotes compassion for the suffering of others. It is also essential to identify where the Weberian state and the relational state can support each other in effectively discouraging abuses of power by police officers. For instance, it may be useful to draw explicit attention to the role of police in navigating between different normative systems as part of police training, as well as discussing the values behind state, religious and customary systems that support the provision of security, particularly in protecting the weak and vulnerable, who are often the most impacted by SARV. If any type of restriction in the role of the police needs to be considered, it should perhaps be a re-prioritising of their role in protecting the vulnerable and de-prioritising the legitimation of a dominating state.

\section{Notes}

1 Official records in PNG, such as court, police and hospital records, are fragmented or inconsistent (Lakhani \& Willman, 2014). They often do not record whether or not a crime or injury resulted from sorcery accusations and lack the vast amount of SARV 
never reported to state authorities. The research team behind this study therefore created a database in late 2016 to be updated until 2020, to detail incidents of sorcery accusations recorded by a network of local researchers in target provinces, using specially devised incident forms to capture violence and non-violence incidents related to cases of sorcery accusations in relevant communities.

2 Further details about the methodology of the project are available at Forsyth, Putt, Bouhours, and Bouhours (2017a).

3 The Sorcery Act 1971 created three main ways to address issues around anxieties about sorcery: offences that indirectly criminalised the practice of pretending to do, or holding oneself out, as practising sorcery; a partial defence for sorcery-accusation related murder; and the offence of falsely accusing someone of performing sorcery or being a sorcerer. When in force, charges were rarely laid under the Act that resulted in convictions in the National court, and records of District court decisions are so fragmented, it is impossible to say how widely it was used at that level, but it may have been used more widely as a strategy for mediation of issues by the police. The defence was almost never used, and indeed the courts since 2010 have been giving heavy penalties more frequently: see further Forsyth (2015, pp. 218-219).

4 See Forsyth, M. et. al. (2019). Ten preliminary findings concerning sorcery accusationrelated violence in Papua New Guinea.

5 See https://un.org.au/files/2013/06/Statement-on-Sorcery-related-Killings-and-Impunityin-Papua-New-Guinea.pdf.

6 The UN recommends a ratio of 1:450.

7 The last recorded figures found were of 1,703 Reserve Police and 3,538 Auxiliary Police in the 2004 review Report, retrieved from: www.inapng.com/pdf_files/Police_ Review_Report_final.pdf.

8 www.inapng.com/pdf_files/Police_Review_Report_final.pdf.

9 www.inapng.com/pdf_files/Police_Review_Report_final.pdf, p. 50.

10 Top cop sidelined over sorcery claim, The National, 29 March 2018.

11 Alleged detained sorcerers released, Post Courier, 8 November, 2017.

12 In one particularly egregious case, the victim had been severely burnt and assaulted; the police detained her in the cells for a day before sending her to the hospital, a delay that was alleged to have led to her death: Woman dies from torture injuries, Post Courier, 1 November 2017.

13 The authors comprising this scholarship include: Shearing, Wood, Braithwaite, Dupont, Grabosky, Wulff, Kyed, Albrecht, Baker, Dinnen, Jean and John Comaroff, Beck and Jaffe, amongst others.

\section{References}

Ashforth, A. (2005). Witchcraft, violence, and democracy in South Africa. Chicago, IL: The University of Chicago Press.

Bayley, D. H., \& Perito, R. M. (2010). The police in war: Fighting insurgency, terrorism, and violent crime. Boulder, CO: Lynne Rienner Publishers.

Braithwaite, J. (2000). The new regulatory state and the transformation of criminology. British Journal of Criminology, 40, 222-238.

Connery, D., \& Claxton, K. (2014). Shared interests, enduring cooperation: The future of Australia-PNG police engagement. Retrieved from https://s3-ap-southeast-2.amazonaws. com/ad-aspi/import/SR72_AFP_PNG_engagement.pdf?8Qt36WDQ4iChLvNyEydnH Zf2FApOBcjJ.

Dinnen, S. (2017). Internal security in Papua New Guinea: Trends and prospects. Retrieved from https://interactives.lowyinstitute.org/archive/png-in-2017/png-in-2017-internal-securitypng-trends-prospects.html. 
Dinnen, S., \& McLeod, A. (2009). Policing Melanesia - International expectations and local realities. Retrieved from www.researchgate.net/publication/232861742_Policing _ Melanesia_-_international_expectations_and_local_realities.

Forsyth, M. (2015). A pluralist response to regulation of sorcery and witcheraft in Melanesia. In M. Forsyth \& R. Eves (Eds.), Talking it through: Responses to sorcery and witchcraft beliefs and practices in Melanesia (pp. 213-239). Canberra: ANU Press.

Forsyth, M. (2016). The regulation of witchcraft and sorcery practices and beliefs. Annual Review of Law and Social Science, 12(46), 331-315.

Forsyth, M., Putt, J., Bouhours, T., \& Bouhours, T. (2017a). In brief 2017/28 sorcery accusation related violence in Papua New Guinea, Part 1: Questions and methodology. Retrieved from http://ssgm.bellschool.anu.edu.au/experts-publications/publications/5782/ ib201728-sorcery-accusation-related-violence-papua-new-guinea

Forsyth, M., Putt, J., Bouhours, T., \& Bouhours, T. (2017b). In brief 2017/29 sorcery accusation related violence in Papua New Guinea, Part 2: Keycharacteristics of incidents, victims and perpetrators. Retrieved from http://ssgm.bellschool.anu.edu.au/experts-publications/ publications/5784/ib201729-sorcery-accusation-related-violence-papua-new-guinea

Forsyth, M., Gibbs, P., Hukula, F., Putt, J., Munau, L., \& Losoncz, I. (2019). Ten preliminary findings concerning sorcery accusation-related violence in Papua New Guinea. Development Policy Centre Discussion Paper No. 80. Retrieved from SSRN: https:// papers.ssrn.com/sol3/papers.cfm?abstract_id=3360817.

Lakhani, S., \& Willman, A. M. (2014). Trends in crime and violence in Papua New Guinea (English). Research and Dialogue Series No. 1. Washington, DC: World Bank Group. Retrieved from http://documents.worldbank.org/curated/en/992741468287127441/Trendsin-crime-and-violence-in-Papua-New-Guinea

Lattas,A., \& Rio, K. M.(2011). Securing modernity: Towards an ethnography of power in contemporary Melanesia. Oceania, 81(1), 1-21. https://doi.org/10.1002/j.1834-4461.2011. tb00090.x

Marks, M., Shearing, C., \& Wood, J. (2009). Who should the police be? Finding a new narrative for community policing in South Africa. Police Practice and Research: An International Journal, 10, 145-155.

Mendez-Beck, M., \& Jaffe, R. (2019). Community policing goes south: Policy mobilities and new geographies of criminological theory. The British Journal of Criminology, 59(4), 823-841. https://doi.org/10.1093/bjc/azy046

Peake, G., \& Dinnen, S. (2014). Police development in Papua New Guinea: The need for innovation. Security Challenges, 10(2), 33-51.

Putt, J., Dinnen, S., Keen, M., \& Batley, J. (2017). The RAMSI legacy for Pacific policing. In Brief 2017/20. Retrieved from https://openresearch-repository.anu.edu.au/bitstream/ 1885/141341/1/IB2017.20\%20Putt\%20et\%20al.pdf

Shearing, C. (2005). Nodal security. Police Quarterly, 8, 57-63.

The Witchcraft and Human Rights Information Network (WHRIN). (2017). Retrieved from www.whrin.org/

World Development Bank. (2017). World Development Report 2017: Governance and the law. Retrieved from www.worldbank.org/en/publication/wdr2017 